\title{
Root-end resection
}

\author{
Blahuta R, Stanko P \\ Department of Dentistry and Maxillofacial Surgery, Comenius University, St. Elisabeth Hospital, Bratislava, \\ Slovakia.r_blahuta@yahoo.com
}

\begin{abstract}
Aim: The aim of the retrospective clinical study was to analyse a complex of patients who underwent a root end resection in the Department of Dentistry and Maxillofacial Surgery, Comenius University, St. Elisabeth Hospital, Bratislava, Slovakia between January 2006 and December 2009 on the small surgery court. Patients: A total number of 285 patients who underwent root end resection.

Methods: Factors examined include sex, patients age structure, total number of resected teeth and their position in upper or lower jaw and the 10 most resected teeth.

Results: From 285 patients 103 (36.14\%) were males and $182(63.86 \%)$ were females. A total number of 378 root end resections was performed, $55(14.55 \%)$ in the lower jaw and $323(85.45 \%)$ in the upper jaw. The most resected teeth are from the first and second quadrant.

Conclusion: There is a decrease trend by the number of patients who underwent root end resection and teeth which were resected in the timeline between 2006-2009. This process is positive and matches the worldwide trend, by making better and successfull endodontic treatment which results in healing of periapical pathology without the need of root end resection (Tab. 2, Fig. 2, Ref. 20). Full Text in PDF www.elis.sk.

Key words: root end resection, periapical pathology, examined factors.
\end{abstract}

Root end resection (RER) or apicoectomy is a operating removal of the apical root tip. Together with root resection and closure of lateral perforations they belong in the area of chirurgical endodontics (1). The main indications for RER are anatomic problems, procedural accidents, irretrievable materials in the root canal, symptomatic cases, and horizontal apical fractures as well as biopsy and corrective surgery (2). Goal of the procedure is the removal of atypical, or complicated aligned apical ramifications with the surrounding in most cases infected tissues. If the root end resection is indicated it should be considered as a extension of nonsurgical treatment, because the underlying etiology of the disease process and the objectives of treatment are the same: prevention or elimination of apical periodontitis (3). Aim of the apicoectomy should be creating a surrounding that helps periodontium to regenerate - eliminate the etiological factors, avoid recontamination of the periradicular tissue, sanation and regeneration of the alveolar bone, periodontal ligaments and cementum covering the root and root end filling $(4,5)$.

\section{Methods}

Analysis of retrospective data on a group of 285 patients who underwent RER in the Department of Dentistry and Maxillofacial

Department of Dentistry and Maxillofacial Surgery, Comenius University, St. Elisabeth Hospital, Bratislava, Slovakia

Address for correspondence: R. Blahuta, MD, Dept of Dentistry and Maxillofacial Surgery, Comenius University, St. Elisabeth Hospital, Heydukova 10, SK-812 50 Bratislava, Slovakia.

Phone: +0905988646
Surgery, Comenius University, St. Elisabeth Hospital, Bratislava between January 2006 and December 2009. The examined factors included sex, patients age structure in the complex, total number of resected teeth and their position in upper or lower jaw and the ranking of the 10 most resected teeth in general.

\section{Results}

Total number of patients and Sex: In the following period 285 pacient underwent RER. $36.14 \%$ were males $(n=103)$ and $63.86 \%(n=182)$ were females. Figure 1 describes the number of patients that were treated each year in the following period depending on sex.

Age structure: The next examined factor was the age structure of the patients who underwent RER in the following period. They have been devided in 6 age groups. Up to $25.26 \%(n=72)$ of all patients were in the (21-30) age group. The other results see (tab. 1).

Total number of resected teeth and their positions in upper or lower jaw: A total number of 378 teeth were resected between January 2006 and December 2009. 2006: 114 teeth, in the year 2007 108 teeth, 200876 teeth and 80 teeth in 2009. $14.55 \%(n=55)$ of the teeth had been resected in the lower jaw and $85.45 \%(n=323)$ in the upper jaw (Fig. 2).

The 10 most resected teeth: The teeth from the first and second quadrant are the most resected. The central and lateral right incisors with a total number of $47(12.43 \%)$ resections each are first ranked. Followed by the RER of lateral and central left incisor 46 $(11.88 \%)$ and $43(11.38 \%)$. Lower ranked are the upper canines and premolars. On the rank 9 and 10 are the central incisors from the fourth and third quadrant (Tab. 2). 


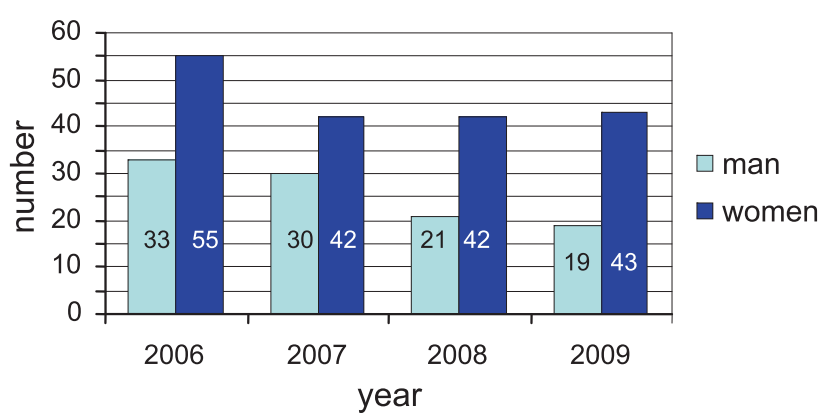

Fig. 1. Number of males and females who underwent RER 2006 till 2009.

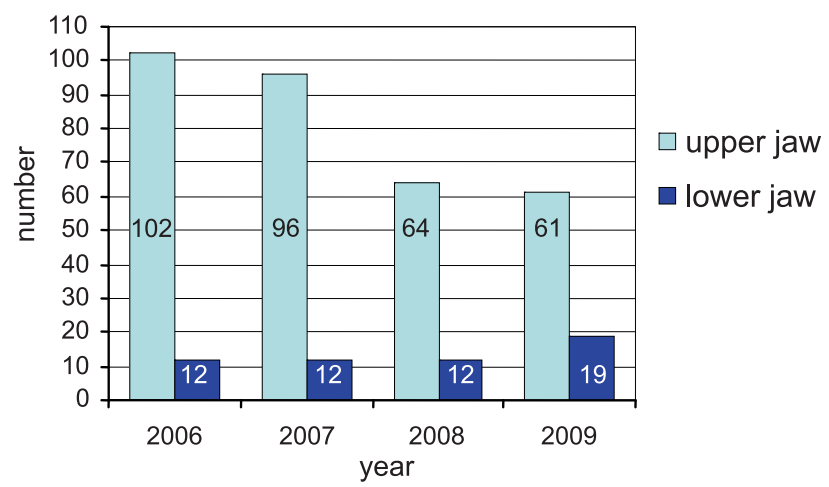

Fig. 2. Total number of teeth resected 2006 till 2009 in upper and lower jaw.

\section{Discussion}

Over the past decade, root end resection has continued to evolve into a precise, biologically based adjunct to nonsurgical root canal therapy. It is a good alternative to extraction and tooth replacement, rather than a treatment of last resort (6). It is for sure a step forward, because RER is not a ideal way to treat a damaged tooth. Thats the reason why nonsurgical retreatment generally is believed to be the prefered first approach in the managment of persistent apical periodontitis $(7,4,5)$.

The findings of this study confirm the worldwide trend by making less RER as a result of persisting periapical pathology, which in most cases is now sucsessfully treated endodontically. We see the decrease on 88 patients treated in 2006, 72 patients in 2007, 63 patients in 2008 and finally 62 patients in 2009 which is $29.55 \%(n=26)$ less

Tab. 1. The age structure of patients who underwent RER from 2006 till 2009.

\begin{tabular}{lrrrrrr}
\hline $\begin{array}{l}\text { year } \\
\text { age }\end{array}$ & 2006 & 2007 & 2008 & 2009 & 2006-2009 & $(\%)$ \\
\hline under 20 & 10 & 8 & 7 & 6 & 31 & 10.88 \\
$21-30$ & 23 & 19 & 15 & 15 & 72 & 25.26 \\
$31-40$ & 14 & 18 & 15 & 12 & 59 & 20.70 \\
$41-50$ & 14 & 7 & 12 & 12 & 45 & 15.79 \\
$51-60$ & 19 & 12 & 9 & 11 & 51 & 17.89 \\
over 60 & 8 & 8 & 5 & 6 & 27 & 9.47 \\
\hline
\end{tabular}

Tab. 2. The ten most resected teeth from 2006 till 2009.

\begin{tabular}{rccc}
\hline rank & tooth number & $\begin{array}{c}\text { total } \\
\text { 2006-2009 }\end{array}$ & $(\%)$ \\
\hline 1 & 11.12 & 47 & 12.43 \\
2 & 22 & 46 & 12.17 \\
3 & 21 & 43 & 11.38 \\
4 & 13 & 38 & 10.05 \\
5 & 23 & 32 & 8.47 \\
6 & 25 & 25 & 6.61 \\
7 & 15 & 21 & 5.56 \\
8 & 14 & 11 & 2.91 \\
9 & 24.41 & 10 & 2.65 \\
10 & 31 & 7 & 1.85 \\
\hline
\end{tabular}

than 2006. This reflects also on the total number of teeth resected each year. A consecutive 3 year decreasing trend with only small increase 2009 by 4 more resected teeth is here present. Still, the diffrence between 2006 and 2009 are 34 less resected teeth. The higher rate of RER in female population could be associated with the fact, that in general women care much more about health than men do.

It is suprising that the age group (21-30) forms $1 / 4(25.26$ $\%)$ of all patients. These patients are very young and accomplish conditions for a favorable endodontic treatment. Wide root canals, less former root canal treatments, less intracanal posts with crowns. Positive is the one of the biggest decrease of resected roots $(n=8)$ in this age group between 2006 and 2009.

The different number of RER in upper or lower jaw is very significant, particular almost 6 time more in the upper jaw. The main reason could be the anatomical - technical problem. Anatomy of the jaws is very different. The access to the root apices expecially in the front region is more favorable in the upper as in the lower jaw $(8,9,10)$. The combination of a shallow vestibule and a longer than average root lenght could complicate acces to the root apex area. In such cases the creation of an osteotomy apical to the root end is just impossible. Curve and the lenght of the roots are also important to watch. Apical anatomy tends to be nonuniform and unpredictable $(11,12,13)$. The lateral maxillar incisor is in some cases difficult to treat endodontically, because of the palatal curve. Lenght of the roots in the upper font region is also more favorable for the better ratio:crown/apex after RER. Another reason could be the higher incidency of teeth injuries in the anterior maxillary region (14). Central and lateral incisors are most affected (15). Overjet is considered a risk factor when it presents values higher than $3 \mathrm{~mm}$ (16). If a vertical root fracture is present in the apical third of the root, it is a indication for RER.

Knowing the incidency of caries in upper and lower teeth can be also helpfull. Several studies of dental caries have been taken among older people $(17,18,19)$ and adults in middle age of life (20). If we take the middle age dental caries life study, there is a conclusion that most of the caries experience between ages 26 and 32 occurred in the posterior teeth, particularly in the upper second premolars, upper molars, lower first molars, and lower second molars. Very little caries experience occurred in the anterior mandibular teeth, while a moderate amount occurred in the anterior maxillary teeth. 


\section{Conclusion}

It is necessary to know, that root end resection is not a option to a fair made convenience endodontic treatment. Nonsurgical treatment generally is believed to be the preferred first approach in the managment of persistent apical periodontitis. The results from our clinical study matches the worldwide trend by making less RER. But there are still few indication, where RER is favorable method compared to extraction.

\section{References}

1. Meechan JG, Greenwood M, Moore UJ, Thomson PJ, Brook UJ, Smith KG. Dentoalveolární chirurgie v praxi zubního lékaře. Praha; Quintessenz, 2007: 55-68.

2. Torabinejad M, Walton RE. Endodontics: Principles and practice. St. Louis: Saunders; 2009: 357-360.

3. Cohen S, Hargreaves KM et al. Pathways of the pulp. ninth ed. St. Louis; Mosby, Elsevier, 2006.

4. Siqueira JF Jr. Aetiology of root canal treatment failure: why welltreated teeth can fail. Int Endodon J 2001; 34 (1): 1-10.

5. Sundqvist G, Figdor D, Persson S, Sjogren U. Microbiologic analysis of teeth failed endodontic treatment and the outcome of conservative retreatment. Oral Surg Oral Med Oral Radiol Endodon 1998; 85 (1): 86-93.

6. Paik S, Sechrist C, Torabinejad M. Levels evidence for outcome of endodontic retreatment. J Endod 2004; 30 (11): 745-750.

7. Briggs PF, Scott BJ. Evidence-based dentistry: endodontic failure-how should it be managed? Br Dent J 1997; 183 (5): 159-164.

8. Cutright B, Quillopa N, Schubert W. An antropometric analysis of the key foramina for maxillofacial surgery. J Oral Maxillofac Surg 2003; 61 (3): 354-357.

9. Moiseiwitsch JR. Position of the mental foramen in a North American, white population. Oral Surg Oral Med Oral Pathol Oral Radiol Endodon 1998; 85 (4): 457-460.
10. Lin L, Skribner J, Shovlin F, Langeland K. Periapical surgery of mandibular posterior teeth: anatomical and surgical considerations. J Endod 1983; 9 (11): 496-501.

11. Mjor IA, Smith MR, Ferrari M, Mannocci F. The structure of dentine in the apical region of human teeth. Int Endod J 2001; 34 (5): 346-353.

12. Ponze EH, Vilar Fernandez JA. The cemeno-dentino-canal junction, the apical foramen and the apical constriction: Avaluation by optical microscopy. J Endod 2003; 29 (3): 214-219.

13. Marroquin BB, El-Sayed MA, Willerhausen-Zonnchen B. Morphology of the physiological foramen. I. Maxilarry and mandibular molars. J Endod 2004; 30 (5): 321-328.

14. Ivancic JN, Bakarcic D, Fugosic V, Majstrovic M, Skrinjaric I. Dental trauma in children and young adults visiting a University Dental Clinic. Dent Traumatol 2009; 25 (1): 84-87

15. Navabazam A, Farahani SS. Prevalence of traumatic injuries to maxillary permanent teeth in 9- to 14-year-old school children in Yazd, Iran. Dent Traumatol 2010; 26 (2): 154-157

16. Cavalcanti AL, Bezerra PK, de Alencar CR, Moura C. Traumatic anterior dental injuries in 7- to 12-year-old Brazilian children. Dent Traumatol 2010; 25 (2): 198-202.

17. Chalmers JM, Carter KD, Fuss JM, Spencer AJ, Hodge CP. Caries experience in existing and new nursing home residents in Adelaide, Australia. Gerontology 2002; 19 (1): 30-40.

18. Luan W, Baelum V, Fejerskov O, Chen X. Ten-year incidence of dental caries in adult and elderly Chinese. Caries Res 2000; 34 (3): 205213.

19. Gilbert GH, Miller MK, Duncan RP, Ringelberg ML, Dolan TA, Foerster U. Tooth-specific and person-level predictors of 24-month tooth loss among older adults. Community Dent Oral Epidemiol 1999; 27 (5): $372-385$.

20. Broadbent JM, Thomson WM, Poulton R. Progression of Dental Caries and Tooth Loss between the Third and Fourth Decades of Life: A Birth Cohort Study. Caries Res 2006; 40 (6): 459-465.

Received June 28, 2010. Accepted January 13, 2012. 